\title{
The Views of State Primary Schools' Teachers about Their Working Conditions
}

\author{
Ali SABANCI* \\ Ramazan GÖK ${ }^{* *}$
}

Received: 11November 2014

Accepted: 14 April 2015

\begin{abstract}
The purpose of this study was to determine the views of teachers who work in state primary schools about their working conditions. The research was conducted in qualitative method. The study group was chosen by maximum variation sampling among teachers who work in Kepez, Antalya. The data were gathered by interviews using a semi-structured interview form. The data were analyzed using content analysis by NVivo 9 programme. As a result, seven categories were identified out of the analysis as social and economical facilities, working settings, the atmosphere about the value of teaching and teachers, promotion and awarding system, relations with management, relations with colleagues and environmental factors. Consequently, teachers stated that they do not have a positive perception about their working conditions. On the other hand, the results asserted that negative views about working conditions were dominated by the positive meaning attached to the profession by teachers themselves and by the society.
\end{abstract}

Keywords: Teaching profession, working conditions, motivation, teacher employment

\section{Extended Abstract}

Purpose and Significance: It can be asserted that teaching profession has been attached of high value and statue by individuals and institutions regardless that they are organized or not, depending on specific reasons. Some of these reasons were stated primarily as employment assurance, to have a regular salary, vacation opportunities and conditions that ease women's other societal responsibilities. Teaching as a profession requires not only to be intertwined with students in and out of the school but also with families and other related agents of the society. On the other hand, physical and psychological conditions of the school environment have a significant effect on teachers' emotions, productivity and their other duties related to the profession.

Comparative data about working conditions of teachers using OECD findings point out to the existence of problems in the working conditions of Turkish teachers. In summary these problems are likely to be 1) Turkey is among the countries that invested the least proportion of the national income in education. 2) Teachers are paid below the average among OECD countries. In this regard, teachers are paid below the poverty threshold. 3) By means of teaching time, Turkish teachers are also below the average of OECD countries. 4) In terms of teacher/student ratios, Turkey was above the average of the OECD countries. The purpose of this paper was to determine the views of teachers about their working conditions.

\footnotetext{
* Corresponding Author: Associate Prof. Dr., Akdeniz University, Antalya, Turkey, alisabanci@akdeniz.edu.tr

** PhD Student, Akdeniz University, rmzngk07@hotmail.com
} 
Methods: This research was based on phenomenological approach which is a kind of qualitative research method. Working group was chosen by maximum variation sampling among teachers who work in Kepez, Antalya. As a result, the working group consisted of eight teachers working in four primary schools. The data were gathered by interviews using a semi-structured interview form. In the interviews, 38 main and probe questions were addressed to the respondents. The interviews were realized face to face. All of the interviews were recorded with a voice recorder and additionally notes were taken to strength the data. The data were analyzed using content analysis by NVivo 9 programme.

Results: As a result seven categories were identified out of the analysis as social and economical facilities, working settings, the atmosphere about the value of teaching and teachers, promotion and awarding system, relations with management, relations with colleagues and environmental factors.

The results show that teachers believed that their salaries were not sufficient to provide basic needs. Moreover, it was found that they worried about their future and these who wish to get married hesitated because of the difficulties of getting along with. Teachers also complained that they were not supported by their superiors in any ways. According to the results teachers believed that they felt shortage of lesson material and extreme work load. They also reported that the profession was less appreciated compared to the past. According to the results, teachers complained about disconnection of the performance and reward system. Another weakness that teachers perceived was about the decision process to which teachers believed not to be included and managers adopted authoritative management style in nature. The findings show also that teachers complained about bureaucratic nature of the profession which they felt they were overloaded by many unnecessary things. One of the most significant things that teachers reported was the disconnection within the groups of teachers based on branches. Parental relationships were also reported to be low level relatively.

Discussion and Conclusions: Consequently, teachers stated that they did not have a positive perception about their working conditions such as the amounts of their salaries, housing benefits, social supports. On the other hand, the results asserted that negative views about working conditions were dominated by the positive meaning attached to the profession by teachers themselves and by the society. The results of these perceptions are likely to cause anxiety and draw teachers to look for various alternative solutions. It can be asserted that teachers are expected to take on responsibility which in fact they cannot overcome by quality and quantity. Teachers proved also that physical conditions are far from providing the needs. Generally, teaching profession was considered to serve the superior goals based on respect, love, training mankind and developing human resources which cannot be evaluated in regard to its social and financial benefits. The award system seems not to be able to motivate teachers to integrate the organization. The findings about management issues show that the authoritarian style, one-sided 
decision making approach and workload drew teachers to feel frustration. Human relations were also a source of disappointment by means of satisfactory work conditions.

Consequently, the findings about the current conditions are not satisfactory in motivating teachers to perform better, willingly and effectively. In this regard, Ministry of National education has a lot to do to make working conditions more attractive and satisfactory. MONE can be advised to build more available physical conditions, provide more efficient instruction materials and help teachers and students access more updated and scientific data. School managers and education authorities should work on providing better relationships and face to face interaction opportunities. 


\title{
Devlet İlköğretim Okulu Öğretmenlerinin Çalışma koşullarına İlişkin Görüşleri
}

\author{
Ali SABANCI $^{* *} \quad$ Ramazan GÖK $^{* * *}$
}

Makale Gönderme Tarihi: 11 Kasım 2014

Makale Kabul Tarihi: 14 Nisan 2015

ÖZET: Bu çalışmada devlet ilköğretim okulu öğretmenlerinin çalışma koşullarına ilişkin görüşleri incelenmiştir. Çalışma nitel araştırma yönteminde desenlenmiştir. Çalı̧̧ma grubu, maksimum çeşitlilik örneklemesi yöntemi ile Antalya ili Kepez ilçesindeki öğretmenler arasından belirlenmiştir. Veriler yarı yapılandırılmış görüşme formu yardımıyla görüşme tekniği ile elde edilmiştir. Veriler NVivo 9 programı da kullanılarak içerik analizine tabi tutulmuş ve değerlendirilmiştir. Çalışmada elde edilen bulgular 1şığında öğretmenlerin çalışma koşulları ile ilişkilendirdikleri faktörler, sosyal ve ekonomik olanaklar, çalışma ortamı, öğretmenlik mesleğinin değerine ilişkin atmosfer, terfi ve ödüllendirme sistemi, yönetimle ilişkiler, meslektaşlarla ilişkiler ve okulun çevresel faktörleri olmak üzere yedi temel faktör belirlenmiştir. Sonuç olarak bütünde değerlendirildiğinde, öğretmenlerin çalışma şartlarını olumlu bulmadıkları anlaşılmaktadır. Bununla birlikte öğretmenlik mesleğine ilişkin kişisel ve toplumsal düzeyde yüklenen olumlu anlamlar nedeniyle çalışma şartlarının ikincil düzeyde değerlendirildiği görülmektedir.

Anahtar sözcükler: öğretmenlik mesleği, çalışma şartları, motivasyon, öğretmen istihdamı

\section{Giriş}

Öğretmenlik mesleğinin toplumsal bellekte "kutsallık" kavramı ile yer edinmiş olması toplumsal değer açısından bu mesleğin diğer mesleklere göre ayırt edici bir özelliği olarak değerlendirilebilir. Bu çerçevede toplumun örgütlü ve örgütsüz tüm birey ve kurumları tarafından kendilerine özgü nedenlerle öğretmenlik mesleğine yoğun bir ilgi gösterildiği söylenebilir. Bu ilginin somut bir göstergesi ise bu mesleğe olan talebin niceliği ve niteliği olabilir. Bu konuda öğretmen adaylarının görüşlerini ortaya koyan çalışmalar bulunmaktadır. Bu nedenler arasında örneğin çocuk sevgisi (\%23), çalışma saatlerinin azlığı/tatil döneminin uzunluğu (\%37.1), iş güvencesinin olması (\%37.1), öğretmenlerinden etkilenme, üniversiteye girişte uygulanan tercih sistemi, aile ve çevre etkisi, öğretmeyi sevmek, öğretmenlerin topluma katkısı ve öğretmenliğin kutsal bir meslek olduğu algısı gösterilmiştir (Boz ve Boz, 2008; Eskicumalı, 2002; Ubuz ve Sarı, 2009). Bu nedenlerin öncelik sırasına ilişkin farklı bulgular bulunmaktadır. Örneğin Özder, Konedralı ve Zeki (2010) öğretmenlik mesleğinin tercih edilme nedenleri arasında öğretmen olma isteğinin iş garantisi ve çalı̧̧ma koşullarından önce geldiğini bulmuştur. Buna karşılık Çermik, Doğan ve Şahin (2010) devlet güvenceli bir iş olması, düzenli maaşa sahip olma isteği, tatil olanaklarının fazla olması ve kadınlar için uygun bir meslek olması şeklindeki "çıkarcı" etkenlerin dışsal, içsel ve özgeci etkenlere göre öncelik kazandığını bulmuşlardır.

Öğretmenlik, devletin eğitim, öğretim ve bununla ilgili yönetim görevlerini üzerine alan özel bir ihtisas mesleği olarak değerlendirilmektedir (Milli Eğitim Temel Kanunu, [MEB], 1973; Sabanc1, 2008). Erden'e (1998) göre, öğretmenlik mesleğinin bazı temel özellikleri şöyle sıralanmaktadır: 1) Öğretmenlik tüm ülkelerde görülen en

** Sorumlu Yazar: Doç. Dr., Akdeniz Üniversitesi, Antalya, alisabanci@akdeniz.edu.tr

Doktora öğrencisi, Akdeniz Üniversitesi, rmzngk07@hotmail.com 
yaygın mesleklerden biridir. 2) Öğretmenlerin çok büyük bir kısmı devlet memurlarından oluşmaktadır. 3) Öğretmenlik mesleğini daha çok toplumun alt sınıflarından gelen bireyler seçmektedir. 4) Öğretmenlik mesleğinin geliri düşüktür. 5) Öğretmenlik mesleğini değiştirenlerin ve terk edenlerin oranı yüksektir. 6) Öğretmenlik mesleğinin toplumsal statüsü çok yüksek değildir. 7) Öğretmenlik mesleği bayanlar tarafından giderek daha çok tercih edilen bir meslek haline gelmektedir. Özden’e (1999) göre öğretmenler eğitim sisteminin en temel öğesidir. Bir ülkenin kalkınmasında, nitelikli insan gücünün yetiştirilmesinde, toplumdaki huzur ve sosyal barışın sağlanmasında, bireylerin sosyalleşmesi ve toplumsal hayata hazırlanmasında, toplumun kültür ve değerlerinin genç kuşaklara aktarılmasında öğretmenlerin başrolü oynamaları beklenmektedir Şişman'ın da (1999) belirttiği gibi, öğretmenlik mesleği insanlarla ilişkiler yönünden diğer bazı mesleklerden farklı olarak geniş bir insan kesimi ile ilişkili ve etkileşim içinde yerine getirilen bir meslektir. Öğretmenlik sadece okul ve sınıf ortamında öğrencilere değil, aynı zamanda okul dışında velilerle ve toplumla da iç içe olan bir meslek türüdür. Öğretmenlik mesleğini seçen kişilerin duyarlılık düzeyleri kendi ruh sağlıklarını da önemli ölçüde etkiler. Çünkü meslek, sadece ekonomik gereksinimlerin karşılanması için değil, aynı zamanda psiko-sosyal gelişim ve doyum sağlamak için de sürdürülen bir uğraştır. Mesleki doyum sağlayamayan bireylerde tükenmişlik sendromu ve stres tepkileri gözlenir (Yazıcı, 2009). Ayrıca Bascia ve Rottmann'1n (2011) da belirttiği gibi öğretimin yapıldığı şartlar öğretmenlerin duyguları, verimlilik algıları ve öğretimle ilgili diğer tüm görevleri üzerinde önemli bir etkiye sahiptir.

Milli Eğitim Bakanlığı'nda halen 824.450 öğretmen görev yapmaktadır (Milli Eğitim İstatistikleri [MEB], 2014). Norm Kadro doluluk oranı ise ülke genelinde \% 86 olarak belirlenmiştir (Avc1, 2013). Buna göre öğretmen açı̆̆ı yaklaşık 134.000 dir. 2014 yılında KPSS Öğretmenlik Alan Bilgisi Testine katılan öğretmen adayı sayısı ise 221.492 olmuştur (ÖSYM, 2014). Eğitim fakültelerinde ve diğer fakültelerde yetişmekte olan öğetmen adayları da dikkate alındığında öğretmenler toplumun geniş bir kesimini oluşturmaktadır. Öğretmenlerin içinde yer aldığı eğitim örgütü ise toplumun tümü üzerinde doğrudan veya dolaylı etkilere sahiptir. Bu durum öğretmenlerin içinde bulundukları sosyal, kültürel ve ekonomik şartları daha da önemli hale getirmektedir. Türkiye'de öğretmenlerin çalışma şartları diğer ülkelerle karşılaştırıldığında çeşitli sorunlar bulunduğu göze çarpmaktadır. Buna göre:

1) Eğitime ayrılan pay ve öğretmen maaşları arasındaki ilişki dikkate alındığında 2008 yılı OECD ülkeleri ortalamasına göre eğitime ayrılan pay \%5.4 olmuştur. Norveç 2008 yılında gayri safi milli hasıladan en yüksek pay ayıran ülke olurken (\%9) Japonya \%3.4' ile en az pay ayıran ülke olarak kaydedilmiştir (OECD, 2012). Türkiye'nin 2012 yılı Merkezi Yönetim Bütçesi tahmini 350. 948. 317. 871 TL olarak hesaplanmıştır. Bu bütçe içinde eğitime ayrılan pay 39. 169. 379. 19 TL'dir. Eğitime ayrılan bütçe 2012 tahmini milli gelirin (GSYH) \%2.75'ine, Merkezi Bütçenin \%11.1'ine karşılık gelmektedir (Merkezi Yönetim Bütçe Kanunu, 2011). Türkiye'de eğitime ayrılan payın OECD ülkeleri içinde en düşük düzeyde kaldığı görülmektedir. 2015 yılında ise 
Merkezi Yönetim Bütçesi tahmini 472. 942. 746.000 TL'dir. Bu bütçe içinde eğitime ayrılan pay 62.000. 248. 000TL' dir (Merkezi Yönetim Bütçe Kanunu Tasarısı, 2015).

2) OECD ülkeleri içinde 2012 verilerine göre (2013 yılında güncellenmiş bilgilerdir) 30 ülke baz alınarak yapılan karşılaştırmada göreve yeni atanan bir ilköğretim okulu öğretmeninin maaşının en yüksek olduğu ülke yıllık 36.610 dolar ile Avustralyadır. Öğretmenin maaşının en düşük olduğu ülke ise 10.362 dolar ile Polonyadır. Buna karşılık Türkiye'de yeni başlayan bir öğretmenin maaşı yıllık 23494 dolardır. OECD ülkeleri arasındaki ortalama maaş değerlerine göre yeni başlayan bir öğretmen maaşı 29.767 dolardır. Buna göre Türkiye'de ilköğretim okulu öğretmen maaşları OECD ülkeleri ortalamasının altındadır. En düşük ve en yüksek maaşlar arasındaki fark oranı ortalaması OECD ülkeleri arasında 1.64 olarak hesaplanmıştır. Türkiye'de bu oran 1.16 ile yine ortalamanın altında bulunmaktadır (OECD, 2012).

3) Asgari geçim standardı ile öğretmen maaşları arasındaki ilişki karşılaştırıldığında dört kişilik ailenin yoksulluk sınırı (tl/ay) 2014 Türk İş’in hesaplamalarına göre Kasım ayında 3.989.80 TL'dir (Türkiye İşçi Sendikaları Konfederasyonu, 2014). Memur Sen (2014) tarafından yapılan hesaplamalara göre ise Mart ayında 3.333.191 TL'dir. Öte yandan 2014 yılında öğretmen maaşlarının en düşükten en yükseğe doğru yaklaşık 2100 TL ile 2500 TL arasında değiştiği söylenebilir. Buna göre dört kişilik bir aile baz alındığında öğretmen maaşlarının yoksulluk sınırının altında olduğu görülmektedir.

4) OECD ülkeleri içinde ilköğretim düzeyinde öğretim süreleri hafta bazında ortalama 38 haftadır. Bu ülkeler içinde 43 hafta ile İsrail en fazla 35 hafta ile Fransa en düşük süre öğretim veren ülkelerdir. Türkiye'de ise hafta bazında öğretim süresi 38 haftadır. Gün bazında ilköğretim düzeyinde öğretim süreleri dikkate alındığında OECD ortalaması 186 gündür. Bu ülkeler arasında Kore 220 gün olmak üzere en fazla İtalya 172 gün olmak üzere en az süre öğretim uygulanmaktadır. Bu süre Türkiye'de 180 iş günü olarak belirlenmiştir.

İlköğretim okulu öğretmenlerinin eğitim için harcadıkları net süreler bakımından OECD ortalaması 779 saattir. Bu bakımdan Şili 1232 saat ile birinci sırada yer almıştır. Finlandiya'da ise bu süreler 677 saat olarak belirlenmiştir. Yunanistan öğretmenlerin 589 saatle eğitim için net olarak en az zaman harcadıkları ülke olarak dikkat çekmiştir. Türkiye'de ise öğretmenlerin net olarak eğitime harcadıkları sürenin 639 saat olduğu görülmektedir. Türkiye'de ilköğretim okulu öğretmenlerinin net olarak eğitime harcadıkları sürenin OECD ortalamasının altında olduğu görülmektedir.

İlköğretim okulu öğretmenlerinin okulda bulunma süreleri bakımından OECD ortalaması 1182 saattir. Bu süreler Şili'de 1760 saat, Birleşik Devletlerde 1381 saat Türkiye'de ise 870 saat olarak belirlenmiştir. Türkiye'de öğretmenlerin okulda bulundukları sürelerinin de OECD ortalamasının altında olduğu anlaşılmaktadır (Education at a Glance, 2011; OECD, 2012).

5) Öğretmen bilgi ve becerilerinin geliştirilmesi açısından 23 OECD ülkesinde yürütülen Talis (2008) araştırmasına göre 6, 7 ve 8 . sınıf öğretmenlerinin son 18 ayda bir mesleki gelişim ile ilgili etkinliğe katılma bakımından İspanya \%100 ile birinci 
sırada yer alırken Türkiye \%74.8 ile 23 ülke arasında sonuncu sırada yer almıştır. OECD ortalaması ise yaklaşık \%88.5'tir. OECD ortalaması yaklaşı 17.5 olan etkinliklere katılma yoğunluğu bakımından da Türkiye ortalamanın altında bulunmaktadır (\%13.6). Bununla birlikte Türkiye'den araştırmaya katılan öğretmenlerin $\% 48.2$ 'si son 18 ayda daha fazla mesleki gelişim etkinliğine katılma ihtiyacı belirtmişlerdir. $\mathrm{Bu}$ oranın da OECD ortalamasının altında olması dikkat çekicidir (\%54.8). Bütünde gelişme gereksinimine yönelik belirlemelerde ise Türkiye sonuncu sırada yer alıştır (\%43). Talis (2008) raporuna göre Malta, Slovenya ve Türkiye öğretmenlerine mesleki gelişim etkinlikleri için hiç parasal destek sağlamamaktadır (OECD, 2009).

6) Devlet memurları, Anayasada ve özel kanununda belirtilen hükümler uyarınca sendikalar ve üst kuruluşlar kurabilir ve bunlara üye olabilirler. Devlet memurlarının greve karar vermeleri, grev tertiplemeleri, ilan etmeleri, bu yolda propaganda yapmaları yasaktır. Devlet memurları, herhangi bir greve veya grev teşebbüsüne katılamaz, grevi destekleyemez veya teşvik edemezler. Öte yandan iş güvencesi ve emeklilik 18. ve 19. maddelerde düzenlenmiştir. Buna göre Kanunlarda yazılı haller dışında Devlet memurunun memurluğuna son verilmez, aylık ve başka hakları elinden alınamaz. Devlet memurlarının, özel kanununda yazılı belirli şartlar içinde, emeklilik hakları vardır. Kademe ilerlemesi ve derece yükselmesi yoluyla memurların görevlerinde ilerleme ve yükselme olanağı tanınmıştır. Mesleki gelişimi teşvik etmek üzere "Yüksek Lisans" derecesini alan öğretmenlere bir kademe ilerlemesi, mesleği ile ilgili öğrenim dalında doktora yapanlara ise iki kademe ilerlemesi uygulanır. Devlet memurları kanununda öğretmenlere ayrıca unvan ve derecelerine göre eğitim-öğretim tazminatı ödemesi yapılmaktadır. Öğretmenlerin başarılarının değerlendirilmesi ve ödüllendirilmesi için ise başarı, üstün başarı ve aylık ödülü öngörülmüştür. Ayrıca okul, kurs veya yaygın eğitim yapan kurumlarda ve benzeri kuruluşlarda öğretmen veya öğretim üyesi bulunmaması halinde öğretmenlere, öğretim üyelerine veya diğer memurlara veyahut açıktan atanacaklara ücret ile ek ders görevi verilebilir (Devlet memurları kanunu [DMK], 1965).

Her derecedeki eğitim ve öğretim kurumları ile Üniversite ve Akademi (Askeri Akademiler dahil), okul, kurs veya yaygın eğitim yapan kurumlarda ve benzeri kuruluşlarda öğretmen veya öğretim üyesi bulunmaması halinde öğretmenlere, öğretim üyelerine veya diğer memurlara veyahut açıktan atanacaklara ücret ile ek ders görevi verilebilir.

7) Öğretmen başına düşen öğrenci sayısı dikkate alındığında OECD ortalaması 21.4 olarak belirlenmiştir. Bu oranlar Kore'de 28.6 ile en yüksek; İzlanda'da 17.9 ile en düşüktür. Türkiye'de ise bu oranın 25.8 ile OECD ortalamasının üstünde olduğu görülmektedir (Education at a Glance, 2011; OECD, 2012).

Kurumlarda işlerin yürümesinde en önemli unsurlardan biri insan faktörüdür. Kurumların daha verimli ve etkili olabilmeleri, rekabet güçlerini koruyabilmeleri ancak çalışanlarının dinamizmine bağlıdır. Çalışanların yüksek performans gösterebilmeleri ve verimli bir şekilde çalışabilmeleri ise ancak onların işlerinden tatmin olmalarına ve 
motivasyonlarına bağlıdır (Eren, 2001). Öğretmenlik mesleği genel olarak özveri ve sevginin esas alındığı gönüllülük içeren bir meslek olarak algılansa da öğretmenlerin de insan olarak ekonomik, sosyal, kültürel veya siyasi açıdan ihtiyaçlarının karşılanması mesleki motivasyon çerçevesinde örgütsel verimlilik ve etkililik açısından büyük önem taşımaktadır. $\mathrm{Bu}$ amaçla çalışmada devlet ilköğretim okullarında görev yapan öğretmenlerin çalışma koşullarına ilişkin görüşlerine dayalı olarak var olan durum betimlenmeye çalışılmıştır.

\section{Yöntem}

\section{Araştırmanın Modeli}

$\mathrm{Bu}$ araştırmada nitel araştırma yöntemi kullanılmıştır. Araştırma nitel araştırma desenlerinden biri olan olgubilim (fenomenoloji) desenindedir. Olgubilim deseni bize tam olarak yabancı olmayan aynı zamanda da tam anlamını kavrayamadığımız olguları araştırmada uygun bir zemin oluşturur (Yıldırım ve Şimşek, 2006). Başka bir deyişle araştırmacı olgubilim deseni ile katılımcılar tarafından tanımlandığı şekliyle insanların bir olgu hakkındaki tecrübelerinin anlamını belirlemeye çalışır (Creswell, 2009).

\section{Çalışma Grubu}

Araştırmanın çalışma grubu amaçlı örnekleme yöntemlerinden maksimum çeşitlilik örneklemesi ile Antalya ili Kepez ilçesindeki ilköğretim okullarında görev yapan öğretmenlerden seçilmiştir (Patton, 1990). Örneklem, 4 ilköğretim okulunda görev yapmakta olan 9 öğretmenden oluşmuştur. Araştırmada yer alan 5 numaralı sınıf öğretmeni görüşme sonrası görüşmenin iptalini istemiş ve bu nedenle araştırmadan çıkarılmıştır. Böylece veriler sekiz öğretmenin görüşüne dayalı olarak değerlendirilmiştir. Sonuç olarak çalışma gurubuna dahil edilen öğretmenlerin özellikleri şöyledir: Öğretmenlerin dördü kadın, dördü erkektir. öğretmenlerden dördü sınıf öğretmeni, dördü ise branş öğretmenidir. Öğretmenlerin tamamı lisans derecesine sahiptir. Öğretmenlerin hizmet süreleri sırasıyla 4, 5, 5, 7, 7, 9, 13 ve 33 yıldır.

\section{Veri toplama Aracı}

Çalışmada veri toplamak amacıyla görüşme yöntemi kullanılmıştır (Yıldırım ve Şimşek, 2006). Bu amaçla yarı yapılandırılmış görüşme formu hazırlanmıştır. Hazırlanan görüşme formu taslağı ile ilgili olarak önce uzman görüşü alınmış daha sonra iki öğretmen ile ön görüşme yapılarak son şekli verilmiştir. Böylece görüşme formunun birinci bölümünde çalışma gurubunun özelliklerini belirlemeye yönelik ikinci bölümünde ise meslekteki çalışma şartlarını belirlemeye yönelik 31 adedi sonda soru olmak üzere 38 soruya yer verilmiştir.

\section{Verilerin Toplanması ve Analizi}

Verilerin toplanması aşamasında katılımcılarla uygun koşullar gözetilerek her bir katılımcı ile yaklaşık olarak birer saat süren yüz yüze görüşmeler yapılmıştır. Geçerlik açısından öncelikle kuramsal bir çerçeve oluşturulmuş; en uygun örneklemin 
seçilmesine, çalışma gurubunun özelliklerinin açıkça belirtilmesine ve veri toplama teknikleri ile analiz süreçlerinin ayrıntılı olarak verilmesine özen gösterilmiştir. Ayrıca, bulgular konu ile ilgili yapılan diğer çalışmalarda elde edilen bulgularla karşıllaştırılmış, çalışmaya katılan öğretmenlerin görüşlerine sunularak teyit edilmesi sağlanmıştır. Güvenirlik açısından araştırmacılar görüşme ortamına ve sürece ilişkin notlar alırken verileri kayıt altına almak için ses kayıt cihazı kullanmıştır. Ses kayıtları daha sonra deşifre edilmiştir. Bu aşamada hata olmaması için deşifre edilen metinler iki araştırmacı tarafından ayrı ayrı kontrol edilmiştir. Veriler analiz aşamasında yararlanılan NVivo 9 programına işlenmiş ve analize hazır hale getirilmiştir. Verilerin analizinde kodlama, temaların bulunması, verilerin kod ve temalara göre organize edilmesi aşamalarından oluşan içerik analizi kullanılmıştır. Veriler, iki araştırmacı tarafından ayrı ayrı kodlanmış ve karşılaştırılmıştır. Ayrıca bulgular frekans ve yüzde hesaplamaları ile desteklenmiştir (Creswell, 2009; Kuş, 2007; Mason, 2002; Patton, 1990; Rubin \& Rubin, 1995; Yıldırım ve Şimşek, 2006).

\section{Bulgular}

Bu bölümde elde edilen bulgular sunulmuş ve yorumlanmıştır. Bu amaçla birinci aşamada öncelikle analiz sonucunda elde edilen genel bilgiler verilmiştir. Bu bilgiler çalışma şartlarına ilişkin boyutlar (Model 1), NVivo programı yardımıyla katılımcıların görüşlerinin kodlama benzerliğine ilişkin 3 boyutlu diyagram (Şekil 1), çalışma şartlarına ilişkin boyutlara göre kodlama dağılımları (Tablo 1) ve kavram haritası ve kullanılma sıklıkları (Tablo 2)' ından oluşmaktadır. İkinci aşamada çalışma şartlarına ilişkin boyutlarda yer alan temalar sunularak yorumlanmıştır (Tablo 3, 4, 5, 6, 7, 8, 9).

Model 1: Öğretmenlerin Çalışma Şartlarına İlişkin Görüşleri

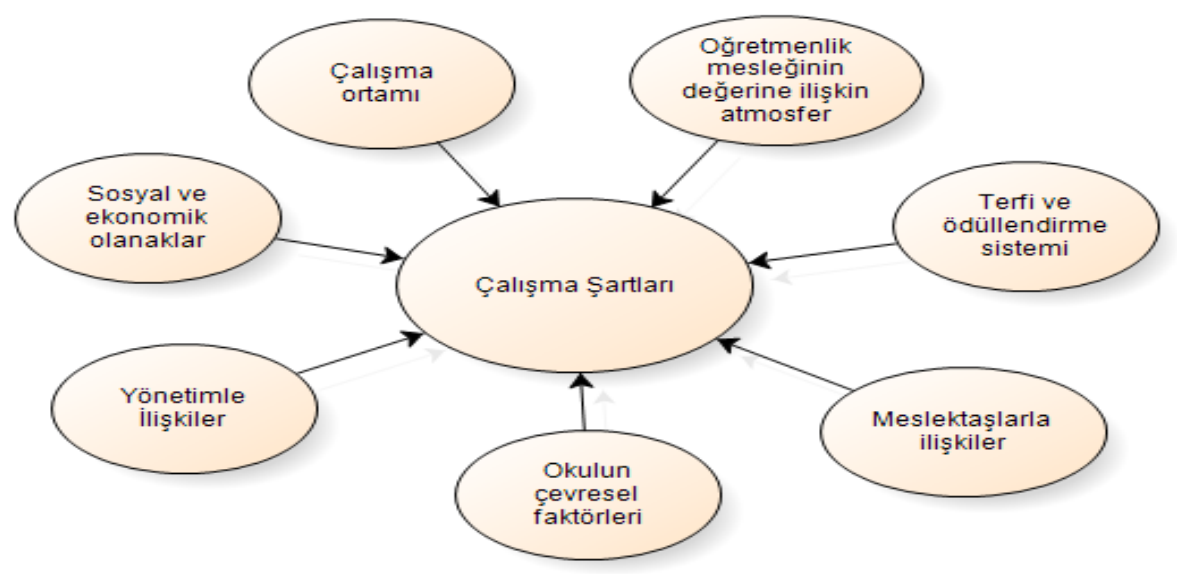

Model 1'de verilen bulgulara göre öğretmenlerin çalışma şartlarını etkileyen faktörlere ilişkin görüşleri sosyal ve ekonomik olanaklar, çalışma ortamı, öğretmenlik mesleğinin değerine ilişkin atmosfer, terfi ve ödüllendirme sistemi, yönetimle ilişkiler, meslektaşlarla ilişkiler ve okulun çevresel faktörleri olmak üzere yedi boyutta toplanmıştır. 
Şekil 1: Öğretmenlerin Görüşlerinin Kodlama Benzerliğine İlişkin 3 Boyutlu Diyagram

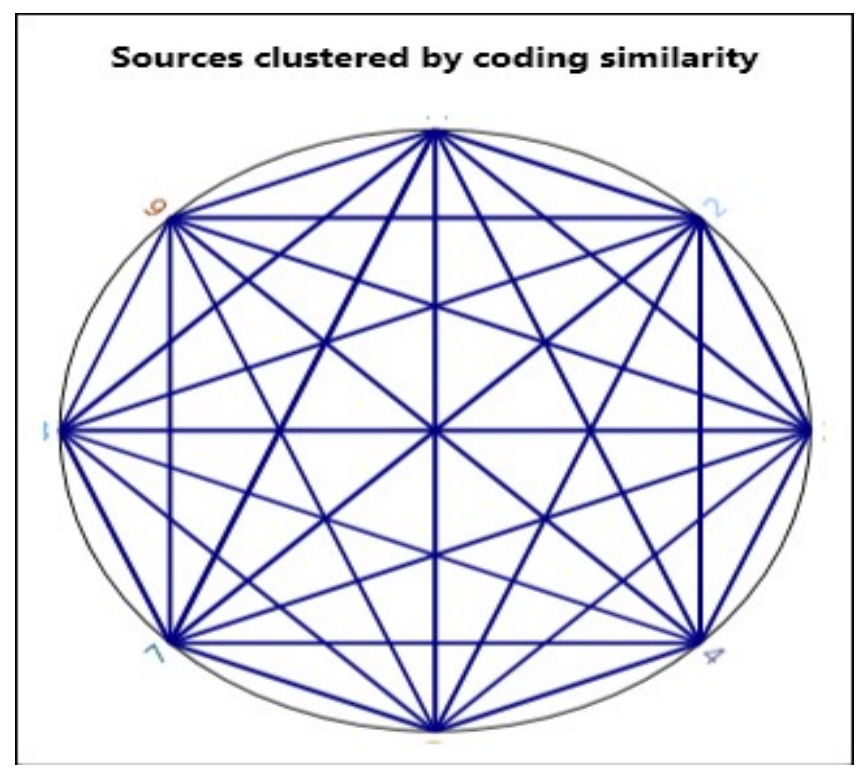

Şekil 1'de verilen 3 boyutlu diyagramda görüldüğü gibi sekiz katılımcının kodlamaları benzerlik göstermektedir.

\section{Tablo 1}

Kodlama (References) Raporu (Matrix Coding Query)

Çalışma Koşullarına İlişkin Kategoriler

1. Sosyal ve ekonomik olanaklar

2. Çalışma ortamı

3. Öğretmenlik mesleğinin değerine ilişkin atmosfer

4. Terfi ve ödüllendirme sistemi

5. Yönetimle ilişkiler

6. Meslektaşlarla ilişkiler

7. Okulun çevresel faktörleri
Öğretmen Kodlama (N)

71

61

39

55

88

14

23

Tablo 1'de verilen kodlama raporunda da görüldüğü gibi en fazla yönetim ile ilişkiler söz konusu olduğunda görüş bildirme ihtiyacı hissettikleri anlaşılmaktadır (88 kodlama). Bundan sonra dikkat çeken faktörler ise sırasıyla meslek örgütünün sunduğu sosyal ve ekonomik olanaklar (71 kodlama), çalışma ortamı ile ilgili faktörler (61 kodlama), terfi ve ödül sistemine ilişkin algılar (55 kodlama), öğretmenlik mesleğinin değerine ilişkin atmosfer (39 kodlama), okulun çevresel faktörleri (23 kodlama) ve en sonunda da meslektaşlarla ilişkiler (14 kodlama) olmuştur. 
NVivo 9 Programı yardımı ile yapılan sözcük analizi sonuçları tablo 2'de sunulmuş ve yorumlanmıştır.

Tablo 2

Öğretmenlerin Görüşmede Kullandıklart Mesleğe Motive Eden Olumlu ve Olumsuz Koşullara İlişkili Kavramlar ve Kullanılma Sıklıkları (word frequency query)

\begin{tabular}{|c|c|c|c|c|c|c|c|}
\hline & $f$ & & $f$ & & $f$ & & $f$ \\
\hline Zaman & 62 & Ben & $\begin{array}{r}12 \\
1\end{array}$ & İmkanlar & 15 & Etkili & 5 \\
\hline Öğretmen & $\begin{array}{r}10 \\
7\end{array}$ & $\begin{array}{l}\text { Biz/arkadaş/ } \\
\text { birlikte }\end{array}$ & 80 & İmkânlarımız & 2 & $\begin{array}{l}\text { Katıliyor- } \\
\text { um/uz }\end{array}$ & $\begin{array}{l}1 \\
1\end{array}$ \\
\hline Fazla & 20 & $\begin{array}{l}\text { Düşünüyoru } \\
\text { m }\end{array}$ & 32 & Öğrenci & 30 & Kişi & $\begin{array}{l}1 \\
8\end{array}$ \\
\hline Sosyal & 18 & Düşünüyoruz & 6 & Çocuk & 24 & Kötü & 5 \\
\hline Eğitim & 21 & Okul & 48 & $\begin{array}{l}\text { Öğrencim/öğrencimi } \\
\text { z }\end{array}$ & 5 & $\begin{array}{l}\text { Motivasyo } \\
\mathrm{n}\end{array}$ & $\begin{array}{l}2 \\
6\end{array}$ \\
\hline Yeterli & 15 & Okulum/uz & 12 & Kararlar & 10 & Motive & 6 \\
\hline Ders & 20 & Maddi & 10 & Güzel & 6 & Uzman & 5 \\
\hline Farkl1/11k & 16 & Adil & 9 & Lojman & 6 & Terfi & 5 \\
\hline Zümre & 13 & Başarı & 23 & Maaş/para & 17 & Gerek & $\begin{array}{l}1 \\
2\end{array}$ \\
\hline $\begin{array}{l}\text { Çalışan/maya } \\
\mathrm{n}\end{array}$ & 28 & Olumlu & 9 & Meslek & 10 & İletişim & 6 \\
\hline İnsan/lar/1m & 37 & Sikıntı & 13 & Yönetim & 11 & İlişki & 8 \\
\hline Etkileme & 26 & Veli/aile & 26 & Ödül/lendirme & 10 & & \\
\hline Biraz/bazen & 17 & Velilerimiz & 2 & Danışılıyor & 9 & & \\
\hline
\end{tabular}

Tablo 2'de verilen mesleki şartlarını ifade ederken başvurdukları sözcüklerin dağılımı analiz edildiğinde, bu sözcükler içinde sözgelimi “öğretmen” sözcüğünün 107 kez kullanılmasına karşılık "meslek” sözcüğünün yalnızca 10 kez kullanılmış olması öğretmenlerin bireysel vurgusu daha güçlü olan öğretmen kavramını önemsediklerinin bir göstergesi olarak kabul edilebilir. Bu durum öğretmenlerde meslek ve örgüt aidiyetinin güçlü olmadığını düşündürmektedir. Benzer şekilde "ben” sözcüğünün 121 kez kullanılmasına karşın bütünleşmenin bir göstergesi olarak değerlendirilebilecek "biz/arkadaş/birlikte" sözcükleri $80 \mathrm{kez}$, kullanılmıştır. Bireysel gönderme anlamı ile 
ele alındığında "düşünüyorum” sözcügünün 32 kez kullanılmasına karşılık bu kavramın çoğulcu karşılığı olan "düşünüyoruz” yalnızca 6 kez kullanılmıştır. Yalın (benim dışımda olan) anlamıyla "okul” sözcüğünün 48 kez kullanılmasına karşılık, aidiyet ya da bütünleşmeye işaret eden "okulum/uz" sözcüğü yalnızca $12 \mathrm{kez;}$; "veli/aile” sözcüğü 26 kez kullanılmışken "velilerimiz" sözcüğü yalnızca 2 kez kullanılmıştır. Yine "öğrenci” sözcüğünün $30 \mathrm{kez}$ kullanılmış olmasına karşılık öğrencim sözcüğünün yalnızca 5 kez kullanılmış olması öğretmenlerin bireysel anlamda öğretmenlik motivasyonlarının yüksek olduğunu ancak meslekle bütünleşme ve kendini mesleğin bir üyesi olarak algılama düzeyinin düşük olduğu şeklinde değerlendirilebilir. Terfi, uzman öğretmenlik ile ilgili kavramların da frekanslarının düşük olması bu yöntem ve araçların öğretmenlik mesleğini cazip k1lmada etkisiz olduğunun işaretleri olarak değerlendirilebilir.

Bu bölümde devlet ilköğretim okulu öğretmenlerinin çalışma koşullarına ilişkin görüşlerine yer verilmiştir. Bu amaçla elde edilen bulgular, çalışma koşulları ile ilgili boyutları ve bu boyutların içeriğini oluşturan maddeleri içerecek şekilde 3, 4, 5, 6, 7, 8 ve 9 numaralı tablolarda sunulmuş ve değerlendirilmiştir. 
Tablo 3

Öğretmenlerin Çalışma Koşullarından Sosyal ve Ekonomik Olanaklar Boyutuna İlişkin Görüşleri

Maddeler

1. Öğretmen maaşları ve görevle ilgili maaş dışı diğer gelirlerin toplamı:

a) Ailelerin temel ihtiyaçlarını karşılamamaktadır. 5

b) Maddi yetersizlikler nedeniyle sosyal, kültürel etkinlik faaliyetleri sınırlı 5 düzeyde olmaktadır.

c) Hem bekâr hem de aile sahibi öğretmenler gelecek kaygısı taşımaktadır. 3

ç) Maddi yetersizlik düşüncesi bekar öğretmenlerin aile kurma durumlarında 3 tereddüt yaratmaktadır.

d) Öğretmenler kendi memleketlerinde (aile çevresi içerisinde) çalıştıklarında 2 ekonomik ve sosyal yönden göreli bir rahatllk hissetmektedir.

2. Müze, ören yeri, sinema, tiyatro ve benzeri mesleki ihtiyaçlara katkı sağlayacak 7 sosyal etkinliklerden yararlandırılma konusunda öğretmenlere bir ayrıcalık tanınmadığı görüşündedir.

3. Öğretmenler öğretmen evlerini ihtiyaçlarını karşılayabilecekleri bir imkân 6 olarak algılamamakta; öğretmenevlerinin zaman zaman kullandıkları ve çoğunlukla öğretmenler dışında kişi ve grupların hizmetinde olduğu kanaatini taşımaktadır.

4. Öğretmenlik mesleğinin yarım gün ve buna göre fazla ücret ödenen bir meslek 3 olduğu şeklinde yanlış bir algı yerleşmiştir.

5. Mevcut lojmanlar nicelik ve nitelik olarak yetersiz görülmekte, ihtiyaç halinde 3 çözüm seçenekleri arasında akla gelmeyecek kadar yok sayılmaktadır.

6. Öğretmenler maddi yetersizlik nedeniyle ek gelir sağlama yönünde bir arayış 2 içindedir.

Tablo 3'te öğretmenlerin çalışma şartları ile ilgili görüşleri sunulmuştur. Buna göre birinci maddede verilen görüşlere göre öğretmenler öğretmenlik mesleğinden elde edilen ücretlerin temel ihtiyaçlarını karşılamadığı, mesleğin bekar veya evli ayrımı olmaksızın gelecek kaygısı oluşturduğu, bekar öğretmenlerin aile kurma durumunda geçim konusunda tereddütler yaşadığı, mevcut gelirlerin ancak aile katkısının sağlanabildiği kendi memleketinde çalışma halinde yeterli olabildiği görüşünü yansıtmışlardır. Katılımcıların bu konudaki görüşleri şöyledir:

Maaşları yeterli bulmuyorum özellikle giderek memur maaşlarına standart, vasıfsız memur maaşlarına yaklaşıyor maaşlarımız (1-a-Ö8).

Tabii ki maddi açıdan zorlandı̆̆ımız zamanlar oluyor (1-a/Ö3). 
Bir ögretmen düzenli şekilde sinemaya tiyatroya gidemiyor. Yani çok ucuzdur belki bilet fiyatları ama ailesiyle birlikte- 4 kişilik ailesi ile birlikte- sinemaya gitmesi bu şartlarda zor (1-b/Ö4).

Şu anda kurs verebiliyorum, ama ileriki zamanlarda daha çok yaşım ilerledikçe de özel bir şeyler yapmak istemediğimde mesela şu anda ben egzersiz veriyorum. Çünkü gencim ama bundan birkaç yıl sonra belki yorulacă̆ım, vakit ayırmak istemeyeceğim ve tabi ki o zaman maaşım bana yetersiz gelecek ve motive etmeyecek (1-c/Ö8).

Tek başıma yaşamımı devam ettirebiliyorum ama bir aile kurumu olduğu zaman bu benim ihtiyaçlarımı karşılar mı? Sosyal kültürel faaliyetler konusunda zaman ayırabilecek miyim? Bütçe ayırabilecek miyim? onun tedirginliğini yaşıyorum açıkçası... (1-ç/Ö6).

Ben memleketim olan bir şehirde yaşadiğım için bütün arkadaşlarımda burada olduğu içinde ben şanslı gruptayım (1-d/Ö4).

Öğretmenlerin 2. maddede belirttikleri görüşlere göre öğretmenlik mesleğinin gerektirdiği asgari toplumsal desteklerin de çalışma koşullarına ilişkin olumlu bir algı oluşturabilecek yeterlikte algılanmadığı anlaşılmaktadır. Bu konuda bir öğretmen görüşünü şöyle ifade etmişstir:

Öğretmen olduğum halde müzeye gireceğim zaman hiçbir şekilde bana bir öncelik tanındı̆̆ını ya da herhangi bir şekilde bana daha farklı bir yaklaşım tarzı gösterildiğini görmüyorum (Ö1).

Öğretmenler öğretmen evleri ile sağlanan hizmetin çalışma koşulları açısından olumlu bir algı yaratabilecek nitelikte olmadığı kanaatindedir. Bu konuda katılımcılardan bazılarının görüşleri şöyledir:

Öğretmenevleri yani artık ögretmenlere sadece isim olarak ögretmenevi hitap ettiği açıdan baktığımız zaman pek de öyle hitap eden bir durumu yok. Ha kötü mü yok iyi böyle bir kimliğimiz var öğretmenevimiz var şeklinde biliyoruz ve ya böyle düşünüyoruz (Ö2).

Ögretmenevleri zaten sadece isim olarak ögretmenevi. Öğretmenlerimizin hiçbirimizin oradan yararlandı̆̆ını düşünmüyorum açıkçası (Ö6).

Tablo 3'te verilen 4. maddede ise mesleğe ilişkin bakış açısını yansıttığı söylenebilecek en yaygın "mit"lerden birine işaret etmektedir. $\mathrm{Bu}$ konuda öğretmenlerden birinin görüşü şöyledir:

Insanlar şu gözle baklyor bir ögrretmen derse giriyor çıklyor yarım gün çalışıyor. Aldı̆̆ para yeter ona diye düşünüyor (Ö1).

5. maddede belirtildiği gibi öğretmenlerin lojman olanaklarından yararlanma fırsatlarına ilişkin büyük ölçüde umutsuz oldukları anlaşılmaktadır. Bu konuda bazı öğretmenlerin görüşleri şöyledir:

Lojman ihtiyacı sadece kırsalda belki insanların ihtiyacını gideriyor olabilir ama lojman imkânlarının yeterli olduğunu düşünmüyorum (Ö6). 
Dediğim gibi lojman yok ve benim çalıştığım okul birçok okula göre iyi. Ben arkadaşlarımdan görüyorum: lojman, elektrik su açısından açısından sıkıntı yaşıyorlar; ayrıca çok ücra yerlerde çalışan da var. O yüzden tatmin edici bulmuyorum (Ö7).

Tablo 3'te verilen 6. madde ise mesleğin maddi kazanç getirisine ilişkin ifade ettikleri "arayış içinde olma hali”" çarpıcı bir gösterge niteliğindedir. Bir öğretmenin bu konudaki görüşü şöyledir:

Ki ben bu mesleği çok sevdiğim halde maddi yetersizlikler nedeniyle pazarda limon mu satsam diye cümleler kurmaya başladım (Ö4).

Tablo 4

Öğretmenlerin Çalışma Koşullarından Çalışma Ortamı Boyutuna İlişkin Görüşleri

Maddeler $n$

1. Üst yönetimlerin öğretmenlerden aşırı beklentileri öğretmenlerde aşırı bir 5 iş yükü oluşturmakta buna karşılık maddi ya da manevi destek vermemeleri hayal kırıklığı yaratmaktadır.

2. Ders araç gereci sağlama konusunda yeterli kurumsal destek 4 bulunmamakta, öğretmenler kişisel çaba ile çözüm geliştirmeye zorlanmaktadir.

3. Okulun fiziki özellikleri hem öğretimsel hem de kişisel ihtiyaçların 3 karşılanmasında yetersizdir.

4. Sınıfları kalabalık olması öğretmenlerin öğrenci başına ayırabilecekleri 4 zamanı kısıtlamaya zorlamaktadır.

5. Teknolojik donanımın yetersizliği, mevcut olan teknolojinin ise eski ya da 3 kullanılamaz oluşu işlerin aksamasına yol açmaktadır.

6. Sınıfın fiziki şartlarının iyileştirilmesi, ısınma ve temizlik yapılması gibi 2 görev dışı ihtiyaçların zaman zaman öğretmenler tarafından karşılanması beklenmektedir.

Tablo 4'te sunulan çalışma ortamına ilişkin çalışma şartlarını betimleyen görüşlere göre 1. maddede üst yönetimlerden beklenen ve ihtiyaç duyulan maddi ve manevi nitelikli desteklerin yeterli olmadığı anlaşılmaktadır. Bu konuda bir öğretmenin görüşleri şöyledir:

Milli ĕgitim çok fazla destek vermiyor. Hep beklentiler var milli ĕgitim tarafindan ve bize destek verilmiyor. Manevi veya maddi anlamda bir destek verilmediği için bu da ögretmenin motivasyonunu düşürüyor (Ö1). 
Tablo 4'te verilen 2. maddede ise etkili öğretimin en temel gereksinimlerinden biri olan ders araç-gereci sağlama konusunda karşılaşılan zorlukların çalışma şartlarını zorlaştırdığı ifade edilmiştir. Bu konuda bazı öğretmenlerin görüşleri şöyledir:

Kendi çabalarımızla kendi imkânlarımızla bir takım araç ve gereçleri temin etmeye çalışlyoruz (Ö1). Matematik dersi ile ilgili bir sürü klavuz kitapta ve ders çalışma kitaplarında materyaller var ama bunların nerdeyse çoğu bende yok (Ö7).

Öğretmenlerin 3. maddede belirttikleri görüşe göre okulun fiziki mekanlarının kişisel ve mesleki ihtiyaçları karşılama açısından tasarlanmadığı anlaşılmaktadır. Bu durumu bir öğretmen şöyle ifade etmiştir:

Birde fiziki şartlar uygun değil. Ĕger bunlar hazır bir şekilde okulda tamamıyla olmuş olsa biz de bu durumda daha etkin daha zamaninda dersi düzgün bir şekilde işleyebiliriz (Ö1).

Tablo 4'te verilen 4. temada sınıfların kalabalık olmaları nedeniyle çalışma şartlarında algılanan zorluklara işaret edilmektedir. Bu konuda katılımcıların görüşleri şöyledir:

Bir kere sınıf mevcutları çok kalabalık (Ö4, Ö8), buradaki sınıflar 45 kişi. Her bir öğrenciye ayırmamı gereken zamanı ayıramıyoruz (Ö8).

Tablo 4'te verilen 5. temada öğretmenler mevcut şartlarda çağdaş teknolojinin gerisinde kalınmasının çalışma şartları üzerinde olumsuz etki yarattığı görüşündedir. $\mathrm{Bu}$ konuda bir öğretmen görüşünü şöyle ifade etmiştir:

Bir sürü şey var tabi eksik olan. Tarih öncesi bilgisayarlar var mesela. Bunun gibi bir sürü şey var tabi eksik olan (Ö8).

Tablo 4'te verilen 6. tema sınıfların fiziki açıdan iyileştirilmesi, 1sıtma ve temizlik gibi görev dışı konularda öğretmenlere sorumluluk yüklenmesi sonucunda çalışma şartlarının olumsuz algılanmasına neden olduğu görülmektedir. Bu konuda katılımcıların görüşleri şöyledir: (Ö4).

Ama ısınma problemi yaşayan okullar var bizde zaman zaman yaşıoruz

Biz kendi çabalarımızla bir şeyler ayarlamaya çalışıyoruz. Atatürk köşesinden tutun mevsim şeritlerine kadar (Ö4). 
Tablo 5

Öğretmenlerin Çalışma Koşullarından Öğretmenlik Mesleğinin Değeri Boyutuna İlişkin Görüşleri

Maddeler

\section{$n$}

1. Öğretmenlik mesleğinin saygınlığının velilerin ve genelde toplumun gözünde 7 azaldığına ilişkin algı oluşmuştur.

2. Öğretmenlik mesleğine ilişkin toplumsal algıda gelişen olumsuz görüşlere 5 rağmen öğretmenler, mesleklerinin yalnızca maddi ve sosyal imkanlarla sınırlandırılamayacak, bir misyon mesleği olduğu inancıyla hareket etmektedir.

3. Öğretmelik değerlendirme ölçütü insan sevgisi olan özel bir meslek olarak 3 algilanmaktadir.

4. Çocukların öğrenmesini ve geleceğini belirleyen bütünde insan yetiştirme 4 sorumluluğu yüklenmiş stratejik önemde bir meslektir.

5. Öğretmenlik mesleği üzerine yüklenen sorumluluk çerçevesinde etkili ancak 4 aynı derecede yetkisi olmayan bir meslek olarak algılanmaktadır.

6. Öğretmenler bilgi, beceri, yaşayış biçimi ve davranışlarıyla örnek alınacak bir 2 model olarak görülmektedir.

7. Öğretmenlerin motivasyonlarının en üst düzeyde olduğu yer ve zaman sınıf ve 2 öğretim anıdır.

Tablo 5'te öğretmenlik mesleğinin toplumda algılanan değeri ile oluşan atmosfere ilişkin öğretmen görüşleri verilmiştir. Öğretmenler toplumda mesleğin saygınlığına ilişkin olumlu algının giderek azaldığı kanaatindedir. Bu konuda bazı öğretmenlerin görüşleri şöyledir:

Hani velilerimizin nazarında bile çok da itibar görmediğimizi söyleyebilirim (Ö6).

Ögretmen deyince insanlar biraz daha bir derli toplu davrantrlar çekinirler ama eskiye oranla müthiş derecede azaldı (Ö4).

Ben bir öğretmen çocuğu olarak annemlerin babamların dönemindeki sohbetlerle bağlantı kurarak söylüyorum müthiş azalma var ilgi eksikliği var (Ö4).

Tablo 5'te verilen 2. 3. ve 4. maddelerde öğretmenlerin üstlendikleri toplumsal rolün bilinci ile mesleklerini değerlendirdikleri söylenebilir. Bu konuda dile getirilen görüşlerin bazıları şöyledir:

Öğretmenlik muhasebecilik ve benzeri mesleklerden farklıdır. Belli kriterleri olan sabit durumu olan mekanik bir iş veya işleyiş değildir. Ancak severek, isteyerek, bilinç ve sorumlulukla yapılabilecek bir meslektir (Ö2). 
Sorumluluklarımız daha fazla çünkü sadece okul sınırları içerisinde değil okul dişında da devam ediyor (Ö6).

Bir insan bir işe isteksiz ise mesleğine aşık değil ise hangi sosyal imkanı ona sunarsanı sunun bahanesi çoktur diye düşünüyorum. Çocukları sevmekle alakalı sosyal imkanlardan daha ziyade (Ö9).

Bence asıl insanların başarısını etkileyen faktörlerden biri kişinin ona inanmasıdır. Mesleğine olan inancı ve sevgisidir (Ö9).

Insan yetiştiriyorsunuz. Bir kere çocuk yetiştiriyorsunuz o çocuğun geleceği sizin elinizin altında” (Ö1).

5. ve 6. maddelerde verilen görüşler yetki ve sorumluluk dengesi ile rol model olma kavramlarının mesleğe ilişkin motivasyon üzerindeki etkisini ifade etmektedir. $\mathrm{Bu}$ konudaki bazı görüşler şöyledir:

Öğretmenlerin yetkileri aslında çok değil ama öğretmenin etkisi çok fazla. Bence etki yetkiyi geçen bir durumdur Etkili olabilmek önemlidir. Insanlar size saygı duydukları ve siz etkili olduğunuz zaman yetki ile aşamayacă̆ınız çoğu şeyi etki ile aşıyorsunuz (Ö9).

Belli bir misyonumuz var onu devam ettirmek zorunda kallyoruz. O ögretmen profiline uygun hareket etmemiz gerekiyor. Kald ki sadece okulda değil okul dışında da ögretmeye devam ediyoruz (Ö6).

Tablo 5'te verilen 7. maddedeki görüşler öğretmenlerin mesleğin çalışma şartlarına ilişkin algılarının yönü ne olursa olsun sınıf içinde yüksek bir motivasyonla işlerine odaklandıklarını ortaya koymaktadır. Bu konuyu bir öğretmen şöyle dile getirmiştir:

Ama sınıfa girince yine de sınıf öğretmenliği çok farklı çocuklar çok farklı olduğu için kapını kapatınca çocuklarla baş başa kalmanın da güzelliği var. Bence bă̆ımsız biraz bizim mesleğimiz (Ö4). 
Tablo 6

Öğretmenlerin çalışma koşullarından Terfi ve Ödüllendirme Sistemi boyutuna ilişkin görüşleri

Maddeler $n$

1. Ödüller çeşitlilik bakımından elde etme çabası göstermeye değer 8 bulunmamaktadır.

2. Kariyer basamakları ödenen ücret farkını meşrulaştıracak bir amaca hizmet 8 etmediğine inanılmasının yanında performans ve başarı ile de ilişkili görülmemektedir.

3. Mevcut ödüllerin nesnel ve adil olarak verilmediğine ilişkin bir alg1 8 yerleşmiştir.

4. Terfi (derece yükselmesi, kademe ilerlemesi) "kağıt üzerinde" yapılan rutin 4 bir uygulama olarak görülmekte öğretmenler tarafından ödül anlamı yüklenmemektedir.

5. Öğretmenler ödüllerin verilmesinde gözetilen ölçütlerin öznel ve bu nedenle 3 belirsiz olduğuna inanmaktadır.

6. Başarı belgesinin verildiği örneklerde mevzuatta belirtilen ölçütlerle 2 uygulama şekli arasındaki tutarsızlık hayal kırıklığı yaratmaktadır.

7. Ödül uygulamasına ilişkin olumsuz algılar nedeniyle öğretmenler okullarla 2 ilişkilerini meslektaş ilişkileriyle ve sınıf içi süreçlerle sınırlı tutmaya yönelmektedir.

Tablo 6'da verilen maddeler terfi ve ödüllendirme sisteminin öğretmenlik mesleğinin çalışma şartlarına ilişkin algılarında olumlu bir etki yaratmadığını ortaya koymaktadır. Buna göre 1. Temada da görüldüğü gibi öğretmenler mevcut ödüllerin erişimin sınırlılığı nedeniyle bu ödülleri elde edemeyeceklerine ilişkin bir algıya sahiptirler. Bu konuda bir öğretmenin görüşü şöyledir:

Terfi ve ödüllendirme sisteminde belli bir kota belli bir sınır konulduğu için tabi bunu da müdür ve idareciler olsun belli sınır ve seviyede verdikleri için bunlar az oluyor (Ö1).

Öğretmenler ödüllerin ve terfilerin performansla ilişkilendirilmemesini önemli bir eksiklik olarak değerlendirmektedir. Bu konuda katılımcıların görüşleri şöyledir:

Bir sınav yaptılar o sınava biz yılımız tutmadı̆̆ için giremedik. Şuan o arkadaşlarımız bizden çok maaş alıyorlar bizden çok mu çalışıyorlar? Yani bir düzensizlik var (Ö4).

Başarı belgesini üç defa alacaksın. Üstüne bir de üstün başarı alacaksın. Onun üstüne bu sefer vali belli bir sayıy uygun görürse üstün başarı alman da 
yetmiyor, ee hadi alabilir dediği için ben bir başarı belgesi aldım ve bu zor alınıyor hani (Ö8).

Tablo 6'da 3. maddede belirtildiği gibi öğretmenler ödüllerin nesnel ve adil olarak verilmediğine inanmaktadır Bu konuda bir öğretmenin görüşü şöyledir:

Onu alan ile almayan arasında somut bir fark olmadığ için bende hiç bir şey fark ettirmiyor. Ama etkin bir fark olsaydı tabi ki uğraşırdım ama şuan somut bir şey göremiyorum (Ö7).

Kademe ve derece ilerlemesi gibi terfilerin performanstan bağımsız olarak verilmesi çalışma şartlarının olumlu algılanması yönünde kısıtlı bir katkı sağlamaktadır. $\mathrm{Bu}$ konuda bir öğretmenin görüşü şöyledir:

Terfiler çok da fazla bir getirisi olmadı̆̆ için sadece kağıt üzerinde kaldığını düşünüyorum (Ö6).

Öğretmenlerin verilen ödüllerde başvurulan ölçütlere ilişkin olumlu bir algıya sahip olmadıkları görülmektedir. Bu konuda bir öğretmenin görüşü şöyledir:

Bir ögretmen mesela iyi nöbet tutmuştur. Bir öğretmen iyi ders anlatmıştır bir ögretmen onu yapmıştır bunu yapmıştır. Değerlendirmenin ölçütüne bağlıdır. Ancak ödüller verilirken bunun gibi ölçütler dikkate alınmıyor. O insanların vicdanı ve sorumluluk alanları ile ilgili bir durum. Adil midir? Genelde adil olmadı̆̆ s söyleniyor (Ö2).

6. maddede mevzuatta belirtilen ölçütlerle uygulamada başvurulan ölçütlerin farklı olduğuna olan inanç ve 7 . temada bütün bu olumsuz algıların sonucunda öğretmenlerin yönetsel konulardan kaçınma şeklinde bir savunmaya yöneldikleri vurgulanmaktadır. $\mathrm{Bu}$ konularda bir öğretmen görüşünü şöyle ifade etmiştir. $\mathrm{Bu}$ konularda bazı öğretmenlerin görüşleri şöyledir:

Diğer başarı belgesi alanları duyduğumda veli ziyareti yaptı̆̆ için mesela bu ilde başarı belgesi verildi. Biz de veli ziyareti yapıyoruz. Bir sürü insan veli ziyareti yapıyor (Ö8).

Ĕ̆er arkadaşlarımla aram iyi ise, ögrencilerim beni tatmin ediyorsa başarı olarak velilerde takdir görüyorsam bunlar beni motive ediyor (Ö7). 
Tablo 7

Öğretmenlerin Çalışma Koşullarından Yönetimle İlişkiler Boyutuna İlişkin Görüşleri

Maddeler

1. Okul yönetimleri haftalık ders planlaması, önemli gün ve haftaların 7 kutlanmasına ilişkin görevlendirmeler söz konusu olduğunda öğretmenlerin görüşlerini alsa da kararları daha çok kendileri almaktadır.

2. Okul yönetimleri adil olmayan, baskıcı, tutarsız ve kayırmacı nitelikte 6 davranışlar sergilemektedir.

3. Tayin ve yer değiştirmeler öğretmenlerde sosyal çevre kaybı veya ekonomik 5 içerikli mağduriyetlere neden olmaktadır.

4. Öğretmenlik mesleği yöneticilerin yarattığı bürokratik işlemlerin yoğunluğu 4 nedeniyle sıkıcı ve yıldırıcı bir hal alabilmektedir.

5. Okul yönetimleri ile ilişkilerin genel olarak olumsuz bir çerçeve içinde yer 4 aldığı düşünülmektedir.

6. Okul yönetimleri öğretmenlere "angarya" olarak tanımlanan görevler 3 vermektedir.

Tablo 7'de öğretmenlerin yönetimle ilişkiler açısından çalışma koşulları ile ilgili görüşleri sunulmuştur. $\mathrm{Bu}$ çerçevede öğretmenler kararların yöneticiler tarafından verildiği görüşündedir. Bu konuda bir öğretmenin görüşü şöyledir:

Karar almak gerektiğinde yöneticilerimiz zaman zaman görüşlerimizi alsalar da genelde kendileri karar verirler (Ö1).

Öğretmenlerin 2. maddede verilen görüşlerine göre okullarda adil olmayan, baskıcı ve kayırmacı bir yönetim anlayışı bulunmaktadır. Bu konuda katılımcıların görüşleri şöyledir:

Kurallar uygulansa ve eşit uygulansa tabi ki motivasyonunu insanın olumlu etkiler. Ben kuralcı bir insan olduğum için kuralların insana mutluluk getirdiğine inaniyorum ama onun herkes tarafindan tam uygulanmasi gerekir. Yani Ahmet yapar Mehmet yapmazsa insanın motivasyonu kırllyor. Kesinlikle olumsuz etkiliyor (Ö4).

Tabi bu sert bir dille kötü bir üslup ile yapılırsa istemem ama disiplinli bir ortamın olmasını isterim tabi ki (Ö7).

Öğretmenlerin 3. maddede belirttikleri gibi yer değiştirme süreci algısal olarak öğretmenlerde çalışma şartlarında zorluk derecesi yaratan bir faktör oluşturmaktadır. $\mathrm{Bu}$ konuda bir öğretmenin görüşü şöyledir:

Insanlar şehirlere yerleşmişler. En basitinden ben ...'de çalıştım geldim tam düzenimi kurdum, rahat edeceğim dediğim zamanda bu tayin işleri çıktı. Böyle olunca tabii motivasyonunuz müthiş kırllyyor (Ö4). 
Öğretmenlerin görüşlerine göre bürokratik işlemler mesleğin gerektirdiği konulara yoğunlaşmada zorluklara neden olmaktadır.

Idarecimiz sadece garantiye almak için işi hani gereksiz bir şey notları mı not çizelgelerini mi hepsini tek tek elle yazdırıyordu bilgisayarla da değil ve bu bana çok angarya geliyordu ve sürekli tartışlyorduk bütün okul onunla (Ö8).

Yetkilerimiz mi kaldı? Sorumluluklarım çok fazla bir kere kağıt kürek işinden oldukça yorulduk (Ö4).

Öğretmenlerin genel olarak yöneticilerle ilişkilerini olumsuz olarak betimlemeleri moral, motivasyon bozukluğu ve sınıf içi performansta düşme gibi sonuçlara neden olabilecek nitelikte görünmektedir. Bu konuda bir öğretmenin görüşü şöyledir:

Oldukça uzun süre kallyoruz biz okulda yönetim ile ilgili mutsuz olduğumuz zamanlarda ben ders yapamam beni kesinlikle etkiler motivasyonumu bayă̆ı aşă̆ıya çeker (Ö4).

Öğretmenlerin yöneticilerle ilgili önemli bir şikayetleri de yöneticilerin kendilerine angarya olarak tanımlanabilecek işler üretmenleridir. Katılımcıların bu konudaki görüşleri şöyledir:

Yöneticilerimiz çok daha kolay ve etkili yöntemlerle çözümlenebilecekken zamanımızı çok alan ve bize yük oluşturacak şekilde çözmeyi tercih ediyorlardı (Ö4).

Idarecimiz sadece işlerini garantiye almak için, hani gereksiz yere, notları, not çizelgelerini ne varsa, hepsini tek tek elle yazdirlyordu bilgisayarla da değil ve bu bana çok angarya geliyordu ve bütün okul onunla sürekli tartışıyordu (Ö8). 
Tablo 8

Öğretmenlerin Çalışma Koşullarından Meslektaşlarla İlişkiler Boyutuna İlişkin Görüşleri

Maddeler

1. Zümre, öğretmenlerin meslektaşlarla ilişkisinin önemsendiği, işbirliği, 8 paylaşım, aidiyet duygusu ve bağlılık gibi davranış ve duyguların karşılanabildiği temel yapı taşı niteliğindedir.

2. Öğretmenler arasında genel olarak meslektaşlarla ilişki kurma arzusu düşük 8 düzeyde, yüzeysel ve teneffüs aralarında öğrenci ile ilgili konularla sınırlı olmak üzere gerçekleşebilmektedir.

3. Öğretmenler arası meslektaş ilişkilerinin kurulabilmesi ile ilgili olarak 6 kurumsal bir girişim bulunmamaktadır. Sosyal ilişkilerin gerçekleşmesi bireysel çabalarla zaman zaman yemek düzenleme ve benzeri faaliyetler şeklinde olabilmektedir.

4. Öğretmenler arasında siyasi, sosyal ve ekonomik yaşam standartları 4 bakımından ayrışmalar bulunmaktadır.

5. Okulda olumlu bir iklim söz konusu olduğunda öğretmenler arasındaki ilişkiler, 4 dayanışma ve paylaşım da olumlu etkilenmektedir.

Tablo 8'de meslektaşlarla ilişkiler bağlamında algılanan çalışma şartlarına ilişkin öğretmenlerin görüşlerine yer verilmiştir. 1. maddede verilen bulgulara göre öğretmenler açısından zümre çalışma şartlarının değerlendirilmesinde olumlu algı yaratan bir işleve sahiptir. Bu konuda katılımcıların görüşleri şöyledir:

Fakat zümre ögretmenleri önemlidir çünkü birlikte çallşıyorsunuz birlikte bir program izliyorsunuz (Ö1).

Zümre olmazsa olmazımız. Yani zümre ekibini gördüğ̈̈nüzde kendinizde daha da fazla çalışma ihtiyacı hissediyorsunuz. Sınıfınız 20 ya da 40 kişi olsa bile sorumlu olduğunuz öğrenci sayısı aslında zümre ögrretmenlerinin bütün ögrencilerini kapslyor. Bütün zümre de kaç öğrenci var, atıyorum 100 öğrenci...Bu 100 kişiyi bir sınıfmış gibi algılıyorsunuz. Zümre arkadaşlarıyla kurulan iyi ilişkilerin başarlyı dengeli ve sistematik olarak etkilediğini düşünüyorum. Şunu söyleyeyim şu an benim sinıfimda mesela, öğretmen arkadaşımı izinli olduğu için öğrencilerini diğer zümre arkadaşıyla paylaştık. Meslektaşlarla olan ilişkilerimiz, paylaşımın niteliği tabii ki motivasyonu artırlyor (Ö2).

Öğretmenler okullarında çalışan özellikle zümre dışı öğretmenlerle yeterli bir ilişki ve iletişim zemini bulunmadığını düşünmektedir. Bu konuda bir öğretmenin görüşü şöyledir: 
Biz çok özel ilişkilere giremiyoruz yani okuldan yorgun argın eve gittiğimiz için öğretmenleri sadece teneffüsler de görebiliyoruz. Sadece selam veriyorsun merhaba diyorsun nasılsın ögretmenim diyorsun ve ya bilgi alışverişinde ancak sorman gereken bir soru ya da danışman gereken bir konuyu ancak görüşüyorsun ya da yarım kalıp geçiyor (Ö4).

Öğretmenlerin kurumsal olarak meslektaş ilişkilerinin geliştirilmesine dayalı bir çabanın olmamasının çalışma şartlarına ilişkin algılarını da olumsuz etkilediği söylenebilir. Bu konuda bir öğretmeninin görüşü şöyledir:

Bir fon oluşturduk. Bu fonla belli günlerde işte ögretmenler gününde yemeğe gittik. Sürekli hale getiriyoruz. Öğretmenler gününde otel ayarlamıştı arkadaşlar oraya gitmiştik kendi imkânlarımızla. $O$ şekilde etkisini de görüyorsun. Yani kaynaşma ancak bu şekilde sağlanıyor (Ö2).

Öğretmenlerin çalışma şartlarını olumsuz algılamalarına neden olan bir faktörün de siyasi, kültürel, sosyal veya ekonomik temelli ayrışmalar olduğu görülmektedir. Bu konuda katılımcıların görüşleri şöyledir:

Insanlar birbirlerini sevmiyor. Görüş ayrllıklarl, siyasi..ne bileyim..sosyoekonomik olabilir hani bir sürü görüş ayrılı̆̆ı var (Ö8).

Yaşam standartları farklı olan arkadaşlarımız olabiliyor (Ö6).

Öğretmenlerin okulda yaratılan olumlu iklimin çalışma şartlarına ilişskin algılarını olumlu etkilediğine ilişkin betimlemeleri bu konuda alınabilecek önlemlere 1ş1k tutabilecek niteliktedir. Bu konuda bir öğretmenin görüşü şöyledir:

Meslektaşlarımızla işbirliği yapabildiğimizde bizi olumlu yönde etkiliyor. Hatta bu okulda işbirliği fena değil. İyi niyetli genç arkadaşlar var bireysel olarak sorunlu olan ögrenciler ile tek tek konuşuyoruz o çocuğa nasıl davranılması gerektiğini. Hatta biz mezun edipte gönderdiysek 67 8'e o çocuklar ile ilgili bilgi veriyoruz. Arkadaşlarımız da iyi niyetle yardımcı olmaya çalışıyorlar (Ö4). 
Tablo 9

Öğretmenlerin Çalışma Koşullarından Okul-Veli-Çevre İlişkileri Boyutuna İlişkin Görüşleri

Maddeler

1. Veliler çocukların genel ihtiyaçları ve öğrenme durumları ile ilgili beklenen 4 katkıyı sağlayamamaktadır.

2. Okul yönetimi ve öğretmenler velilerle gerektiği kadar ilgilenmemekte; ihtiyaç 3 duymaları halinde akademik destek vermemektedirler.

3. Okul yakın ve uzak çevreden ihtiyaç duyulan nitelikte katkı 3 sağlayamamaktadır.

4. Öğretmenlerle veliler arasında sağlıklı bir ilişki kurulamamakta; veliler, 2 öğretmenlere yönelik ön yargılı, kırıcı ve baskıcı tutum sergileyebilmektedir.

Tablo 9'da öğretmenlerin okulun çevresel faktörleri bakımından çalışma şartlarına ilişkin betimlemelerini içermektedir. Öğretmenler velilerin okulla olan ilişkilerinin beklenen nitelikte olmadığını vurgulamaktadırlar.

Model olarak çocuğun önünde sadece siz varsınız 14:30 'da sizden ayrldiktan sonra en basitinden 'soba' kelimesi. Öğrenciye soba dedirtmeye uğraşıyorsunuz ama evde annesi soba demez de 'zoba' derse... çok basit örnek veriyorum. Yani ailenin de eğitime katkısı çok önemli (Ö4).

Velilerin katkılarının yetersiz olmasının çok sayıda nedeni olduğu söylenebilir. Ancak 2. maddede betimlenen öğretmenlerin bu konuda ne öğretmenlerin ne de yöneticilerin velilerin etkin katılımı konusunda yeterli çabayı göstermediklerini düşünmeleri ve dördüncü maddede betimlenen aslında ilişkilerin karşılıklı olarak olumsuz olduğuna dair çok ayıda verinin bulunması bütüncül bir yaklaşıma olan ihtiyacı vurgulamaktadır. Bu konuda katılımcıların görüşleri şöyledir:

Ailelerin ciddi bir eğitime ihtiyaçlart var. Özellikle okulumuzun bulunduğu çevre bunu gerektiriyor. Çünkü aile bireylerinin bu konuda dikkatli olmayışları aile kurumunun sağlam olmayışı çeşitli problemlerin oluşu yine çocukların bu anlamda bize eksik gelmelerine sebep oluyor. Bu anlamda bize çok iş düşüyor. Hem ögretmenlere, hem yöneticilere çok iş düşüyor. aslında genelde okul aile iş birliği sağlanamadıkça yine eksik kalıyor (Ö6).

Sinıf içinde de sınıf dışında da veli ya da yönetim dersinize girmediği halde ya da ögrenci sizi eleştiriyor ve bu eleştiriler gerçekten haksız eleştiriler olabiliyor bazen. çok önyargılı oluyor ve bir şey yapmak istemiyorsunuz (Ö7).

3. maddeye göre öğretmenler aile dişındaki çevresel faktörlerin de okula etkin bir katkı sağlamadıkları görüşündedir. Bu konuda katılımcıların görüşleri şöyledir:

Okulumuzun çevresel faktörlerinde biraz sıkıntı olduğu için bazı imkânlar sıkıntılı (Ö1). 


\section{Tüm çevrenin bir bütün olarak ögrrencilerin eksikliklerinin giderilmesinde çalışmasını isteriz (Ö3).}

\section{Sonuç ve Tartışma}

İlköğretim okulu öğretmenlerinin çalışma koşullarına ilişkin görüşlerinin betimlenmesi amacıyla yürütülen bu çalışmada öğretmenlerin çalışma koşulları ile ilişkilendirdikleri sosyal ve ekonomik olanaklar, çalışma ortamı, öğretmenlik mesleğinin değerine ilişkin atmosfer, terfi ve ödüllendirme sistemi, yönetimle ilişkiler, meslektaşlarla ilişkiler ve okulun çevresel faktörleri olmak üzere yedi temel faktör belirlenmiştir.

Elde edilen verilerin sözcük düzeyinde analiz edilmesiyle elde edilen sonuçlara göre öğretmenlerin kişisel olarak öğretmenlik mesleğini benimseme durumları öne çıkarken örgüt ve çalışma şartları söz konusu olduğunda ifadelerin olumsuz yönde değiştiği görülmektedir. Kullanılan kavramlar öğretmenlerin örgütsel bağl1lık ve örgütle bütünleşme boyutlarında önemli sorunlar olduğuna işaret etmektedir.

Öğretmenlerin sosyal ve ekonomik olanaklara ilişkin görüşleri bütünde değerlendirildiğinde görevde olan öğretmenlerin öğretmenlik mesleğini maddi ve sosyal olanaklar açısından cazip buldukları söylenemez. Sonuçlara göre elde edilen ücretler, lojman, öğretmen evi gibi sosyal olanaklar ve diğer toplumsal ayrıcalıklar açısından mesleki şartların olumlu algılanmadığı anlaşılmaktadır. Bu durumun öğretmenlerde kaygı yarattığı ve gelir elde etme yönünde farklı arayışlara neden olduğu görülmektedir. Nitekim Bozkurt ve Bozkurt'un (2008) ve Barlı, Bilgili, Çelik ve Bayrakçeken'in (2005) çalışmalarında da öğretmenlik mesleği ile elde edilen ücret ve toplam gelirlerin büyük oranda tatmin edici olmadığı belirlenmiştir. Bu çerçevede ücret artışlarında da çok büyük oranda memnuniyetsizlik dile getirilmiştir. Gündüz ve Can'ın (2011) çalışmalarında da maaşların günün ihtiyaçlarının gerisinde kaldığı öğretmenlik mesleği ile elde edilen özlük hakları konusunun öğretmenler tarafından yüksek düzeyde sorun olarak görüldüğü belirlenmiştir. Ayrıca bu çalışmada ortaya çıkan öğretmenlik mesleğinin yarım gün ve buna göre fazla ücret ödenen bir meslek olduğu şeklindeki yanlış bir algının bulunduğu görüşü Gündüz ve Can'ın (2011) öğretmenlerin günlük ders saatinin fazla olduğuna inandıkları bulgusu ile desteklenmektedir.

Çalışma ortamı açısından öğretmenlerin algılarına göre üst yönetimlerin ve okul yönetiminin öğretmenlerden beklentileri yüksektir. Öğretmenler yönetimlerin bu beklentilerde aşırılığa yöneldikleri görüşündedir. Buna karşılık beklenen görev sorumlulukların yerine getirilmesinde aynı derecede desteğin sağlanmaması sonucunda nicelik ve nitelik yönünden öğretmenlerin baş edemeyecekleri bir yükümlülüğün ortaya çıktığı anlaşılmaktadır. Bu konuda örneğin Bozkurt ve Bozkurt (2008) öğretmenlerin kişisel ve mesleki gelişim ile ilgili ihtiyaçlarının karşılanması konusunun kendileri açısından önemli bir sorun oluşturduğunu belirlemiştir. Ders araç-gereci ve teknoloji kaynakları konusunda ki yetersizlik Çankaya ve Tan'ın (2010) bulguları ile örtüşmektedir. Buna göre problemlerin çözümü, araç-gereç temini sürecindeki sorunlar öğretmenlerde daha fazla strese neden olmaktadır. Genel olarak görev, fiziksel koşullar, 
roller ve kişiler arası ilişkiler, ekonomik, politik ve teknolojik belirsizlikler, disiplin problemleri ve okulun kötü yönetimi gibi çeşitli kaynaklarla bağlantılı olarak öğretmenlerin orta düzeyde stres yaşadığı belirlenmiştir (Sabancı, 2011). Benzer şekilde teknik donanımın yetersizliği, hijyen ile ilgili yetersizlikler ve okuldaki fiziki mekanların hem öğretimsel hem de kişisel ihtiyaçları karşılamaktan uzak olarak algılanmasının öğretmenlerin çalışma koşullarına ilişkin algılarında negatif yönde etkiler yaratacağı söylenebilir. Okuldaki fiziki koşulların kişisel ve mesleki olarak tatmin edici olmadığına ilişkin bulgu çeşitli çalışmalarla desteklenmektedir. Bu konuda Barlı ve diğerleri (2005) ve Gündüz ve Can (2011) okulun fiziksel şartlarının ve olanaklarının öğretmenler tarafından önemli bir sorun olarak algılandığını belirtilmiştir. Bunun sonucunda örneğin LaHuffman-Jackson'ın (2009) da belirttiği gibi çalışma şartları iyi olarak algılanmayan okullarda öğretmen devri de yüksek olmaktadır. Ayrıca bu durumun öğretmenlerde tükenmişlik, iş doyumsuzluğu ve benzeri duyguları ortaya çıkarmasına ve mesleğe olan tutum ve davranışlarda olumsuzluklarla karşılaşılmasına neden olabileceği söylenebilir. Gündüz (2005) sosyal destek alan öğretmenlerin sosyal destek almayanlara göre daha az tükendikleri bulmuştur. Ayrıca sınıfların kalabalık olmasıyla ortaya çıkan olumsuz çalışma şartlarının öğretmenlerde tükenmişliğe yol açtığına ilişkin bulgular mevcuttur (Cemaloğlu ve Şahin, 2007).

Öğretmenlerin gözlemlerin dayalı olarak belirtilen öğretmenlik mesleğinin saygınlığının azaldığına ilişkin benzer bulgular mevcuttur. Örneğin Karamustafaoğlu ve Özmen (2004) öğretmen adaylarının öğretmenlik mesleğinin eskiye oranla saygın görülmediği görüşünde olduklarını belirlemişlerdir. Genel olarak mesleğe ilişkin saygınlık konusunda farklı görüşler olmakla birlikte bütünde değerlendirildiğinde mesleğe ilişkin toplumdaki genel atmosferin, saygınlı, sevgi, insan yetiştirme gibi kutsal bir görev, sosyal ve maddi olanakları ile ölçülemeyecek, toplumun rol modeli ve benzeri kavramlarla örülmüş olan üstün amaçlarla biçimlendiği görülmektedir. Nitekim öğretmenlerin yaptıkları işi büyük oranda "zevkli" bulduklarına ilişkin bulgular da mevcuttur (Bozkurt ve Bozkurt, 2008). Sonuç olarak mesleği isteyerek yapan ve manevi doyum sağlayan öğretmenlerin daha az tükenmişlik yaşadıkları belirlenmiştir (Cemaloğlu ve Şahin, 2007).

Mevcut ödül ve terfi sisteminin tür, çeşitlilik, ihtiyacı karşılayabilme ve genelde uygulama süreçleri bakımından öğretmenlerde meslekle bütünleşme duygusu yaratmadığı, aksine çalışma şartlarına ilişkin moral bozukluğu ve motivasyon düşüklüğüne neden olduğu söylenebilir. Bu konuda Barlı ve diğerleri (2005) meslekte yükselme olanaklarının öğretmenlerde düşük motivasyona yol açtığını belirtmişleridir. Bozkurt ve Bozkurt'un (2008) bulguları da öğretmenlerin terfi olanaklarının sınırlılığının çalışma şartlarının olumsuz algılanmasında en önemli sorunlardan biri olduğunu göstermektedir. Çankaya ve Tan (2010) maddi sosyal destek niteliğindeki kariyer desteğinin mevcut durumunun öğretmenlerde ödül desteğine göre daha fazla strese neden olduğunu belirtmektedir. Gündüz ve Can (2011) kıdem ile maaş ve ek ders ücretleri arasında anlamlı ilişkinin bulunmamasının da öğretmenler tarafından bir sorun olarak görüldüğünü belirlemiştir. Ayrıca etkileri açıkça hissedilen ancak mevzuat 
düzenlemelerinde öngörülmeyen söz, mimik ve davranışlarla ifade edilen ödül ve ceza uygulamalarının da öğretmenler üzerinde olumsuz etkiler yarattığı görülmektedir. Bu bakımdan dışlama, ötekileştirme, selam vermeme, suratını asma ve benzeri psikolojik yıldırmaya varan söz ve davranışların da göz ardı edilmemesi gerekmektedir.

Yönetsel ilişkiler konusunda elde edilen bulgular okulda yönetsel uygulamaların ve ilişskilerin gerçek çerçevesinin tek taraflı kararlar, baskıcı bir anlayış, gereksiz iş üretme ve öğretmene yükleme ve olumsuzluk durumunda öğretmenlerin zarar görebileceklerine ilişkin kaygı yaratma şeklinde öğelerle şekillendiği söylenebilir. Bu görüş başka çalışmalarla da desteklenmektedir. Örneğin Gündüz ve Can (2011) öğretmenlerin yönetim ile ilişkilerini çok sorunlu gördüklerini bulmuşlardır. Benzer şekilde Cemaloğlu ve Şahin'in (2007) çalışmalarında üstlerinden takdir görme ve mesleki verimlilik açısından değerlendirilme konusu öğretmenlerin tükenmişlik yaşadıkları konulardan bir olarak belirlenmiştir. $\mathrm{Bu}$ yönüyle mevcut yönetsel uygulamaların öğretmenlerde yalnızca yönetici olma arzusunu olumsuz etkilemekle kalmadığı aynı zamanda öğretmenlik mesleğine ilişkin motivasyonu da düşürdügü ileri sürülebilir. $\mathrm{Bu}$ çalışmada kararlara katılmaya ilişkin öğretmen görüşlerine başvurulmakla birlikte son kararı yöneticinin verdiği belirlenmiştir. Bozkurt ve Bozkurt (2008) tarafından yapılan çalışmada ise öğretmenlerin karara katılım imkânı verilmesi konusunda önemli bir sorun görmedikleri belirlenmiştir.

Meslektaş ilişkileri genel olarak değerlendirildiğinde öğretmenler arasında sosyal ve mesleki yönden zayıf olarak nitelenebilecek bir ilişkinin var olduğu anlaşılmaktadır. Meslektaşlar arasındaki ilişki ise zümre düzeyinde kısmen daha sağlıklı ve mesleki aidiyet yaratabilecek düzeyde motive edici özel bir yap1 olarak tarif edilmektedir. Bununla birlikte okuldaki öğretmenler, aynı ilçe ya da ilde görev yapan diğer öğretmenler ve eğitim örgütü bir bütün olarak düşünüldüğünde kişisel veya kurumsal yönden sosyal ilişki ihtiyacının karşılanması açısından öğretmenler için cazip koşullar oluşmadığı anlaşılmaktadır. Bu çalışmada öğretmenler arasında genel olarak meslektaşlarla ilişki kurma arzusunun ve olanaklarının düşük düzeyde olduğu belirlenmiştir. $\mathrm{Bu}$ bulgu Bozkurt ve Bozkurt'un (2008) bulguları ile kısmen örtüşmektedir. Buna göre arkadaşlık ilişkileri ile kurum içi iletişimin etkililiği orta ve alt düzeydedir. Çankaya ve Tan'ın (2010) çalışmalarında ise ödüllendirilme, yardım almak ve sosyal etkinlikler, motivasyon, şeklindeki duygusal nitelikli desteklerin göreli olarak maddi nitelikli desteklere göre daha az stres yaratan faktörler oldukları belirlenmiştir. $\mathrm{Bu}$ çalışmada elde edilen sonuçlara göre öğretmenler siyasi-sendikal, sosyal ve ekonomik içerikli büyük farklılıkların ve ayrışmaların bulunduğu algısını dile getirmektedir. $\mathrm{Bu}$ durumun da çalışma şartlarının algılanması açısından olumsuz sonuçlara neden olacağı ileri sürülebilir.

Okulun çevresel faktörleri açısından öğretmenlik mesleğine ilişkin öğretmenlerin motivasyonları değerlendirildiğinde iki yönlü olarak okul aile işbirliğinin veya ilişki biçiminin tatminkâr olmadığı, öğretmenlerin kendileri ile ilgili beklentilere karşı1ık veremedikleri gibi çevrenin de öğretmenlerin beklentilerini karşılamada yetersiz kaldığ1 anlaşılmaktadır. Bu haliyle çevresel faktörlerle ilişkinin öğretmenlik çalışma 
şartlarına ilişkin olumlu bir atmosfer yaratmadığı söylenebilir. Nitekim Sabanci (2009) öğretmenlerin çevreye karşı duyarlılık boyutunda tükenmişlik düzeylerinin yüksek olduğunu bulmuştur. Ayrıca çevrenin sosyo-ekonomik durumu ile öğretmenlerin tükenmişlik düzeyleri arasında da anlamlı bir ilişki olduğu bulunmuştur (Cemaloğlu ve Şahin, 2007).

\section{Öneriler}

Bütünde değerlendirildiğinde öğretmenlik mesleğine ilişkin çalışma şartlarının öğretmenleri mesleğe motive etme bakımından güçlü olmadığı söylenebilir. Bu bakımdan Milli Eğitim Bakanlığı'nın okulların fiziki şartlarını hem öğretime uygunluk hem de öğretmenlerin kişisel ve mesleki ihtiyaçlarını karşılayacak şekilde yeniden değerlendirmesi beklenir. Öğretmenlerin mesleklerini etkili bir şekilde yapabilmeleri için gereken araç- gereç, bilgi ve teknolojilere erişim güncel ihtiyaçlara göre düzenlenmeli ve kolaylaştırılmalıdır. Maaş, maaş dışı maddi içerikli faydalar ile ödül ve terfi sisteminin mesleki motivasyonlarını artırma yönünde öğretmenlerin ihtiyaçlarından hareketle düzenlenmesi en başta toplumun geleceği emanet edilen öğretmenlerin gelecek kaygılarının ortadan kaldırılması açısından önemlidir. Ödüllendirmede ve maaş dışı maddi nitelikli faydaların elde edilmesinde hakkaniyet ölçülerinde adil, şeffaf ve amaca uygun bir uygulama için gereken düzenlemeler yapılmalıdır. Öğretmenlerin özlük durumları mesleği cazip kılacak nitelikte olmalıdır. Öğretmenevleri, lojman ve benzeri sosyal düzenlemeler öğretmenlerin tam zamanlı, her yaş gurubuna ve her yerde öğretme sorumluluğuna ilişkin toplumsal beklenti gözetilerek yapılmalıdır. Öğretmenler arasındaki ilişkilerin meslektaşlar arasında güçlü bağlar oluşturacak şekilde geliştirilebilmesi bireysel girişimlere fırsat tanımanın yanında bir de kurumsal boyutta düzenlemeler ve girişimlerle mümkün görünmektedir. Benzer çalışma okul öncesi ve orta öğretim kurumlarında; özel ilk ve ortaöğretim kurumlarında da yapılabilir. Ayrıca diğer mesleklerle karşılaştırmalı olarak çalışma şartlarının değerlendirilmesi önerilebilir. 


\section{Kaynakça}

Avcı, N. (2013). Milli Eğitim Bakanı. 2014 Yılı Bütçe Sunuşu TBMM Genel Kurulu. http://sgb.meb.gov.tr/meb_iys_dosyalar/2013_12/25103155_butce_sunusu_2014.pd f adresinden alınmıştır.

Bascia, N. \& Rottmann, C. (2011). What's so important about teachers' working conditions? The fatal flaw in North American educational reform. Journal of Education Policy, 26(6), 787-802.

Barlı, Ö., Bilgili, B. Çelik, \& Bayrakçeken, S. (2005). İlköğretim okul öğretmenlerinin motivasyonları: farklılıkların ve sorunların araştırılması. Atatürk Üniversitesi Sosyal Bilimler Enstitüsü Dergisi,5(1), 391-417

Boz, Y. \& Boz, N. (2008). Kimya ve matematik öğretmen adaylarının öğretmen olma nedenleri. Kastamonu Ĕ̈itim Dergisi, 16(1), 137-144.

Bozkurt, ö. \& Bozkurt, i. (2008). İş tatminini etkileyen işletme içi faktörlerin eğitim sektörü açısından değerlendirilmesine yönelik bir alan araştırması. Doğuş Üniversitesi Dergisi, 9(1), 1-18.

Cemaloğlu, N. \& Şahin, D. E. (2007).Öğretmenlerin mesleki tükenmişlik düzeylerinin farklı değişkenlere göre incelenmesi. Kastamonu Eğitim Dergisi, 15(2), 465-484.

Creswell, J. W. (2009). Research design qualitative, quantitative, and mixed methods approaches (6th Ed.). California: SAGE Publications. Inc.

Çankaya, İ. H. \& Tan, Ç. (2010). Öğretmenlerin algılarına göre okul temelli sosyal destek ve stres arasındaki ilişki. Fırat Üniversitesi Sosyal Bilimler Dergisi. 20(2), 211-221.

Çermik, H., Doğan, B., \& Şahin, A. (2010). Sınıf öğretmenliği öğretmen adaylarının öğretmenlik mesleğini tercih sebepleri. Pamukkale Üniversitesi Eğitim Fakültesi Dergisi, 28, 201-212.

DMK. (1965). Devlet memurları kanunu. Kanun Numarası: 657. Resmi Gazete, 12056.

Education at a Glance (2011). How much time do teachers spend teaching? http://www.oecd-ilibrary.org/education/education-at-a-glance-2011_eag-2011-en. (20.05.2012)

Erden, M. (1998). Öğretmenlik mesleğine giriş. İstanbul: Alkım Yay.

Eren, E. (2001). Örgütsel davranış ve yönetim psikolojisi. İstanbul: Beta Yayınları.

Eskicumal1, A. (2002). Öğretmenlik mesleğine giriş. Y. Özden (Ed.). içinde Eğitim, ögretim ve öğretmenlik mesleği. Ankara: Pegem A Yayıncılık.

Gündüz, B. (2005). İlköğretim öğretmenlerinde tükenmişlik. Mersin Üniversitesi Eğitim Fakültesi Dergisi, 1(1), 152-166.

Gündüz, Y. \& Can, E. (2011) Öğretmenlerin eğitim sistemi ve uygulamalarına ilişkin güncel sorunları algılama düzeylerinin incelenmesi. Türk Eğitim Bilimleri Dergisi, 9(4), 745-774. 
Karamustafaoğlu, O. \& Özmen, H. (2004). Toplumumuzda ve öğretmen adayları arasında öğretmenlik mesleğine verilen değer üzerine bir araştırma. Değerler Ĕ̈itimi Dergisi, 2(6), 35-49.

Kuş, E. (2007). Nicel-nitel araştırma teknikleri. 2. Baskı. Ankara: Anı Yayıncılık.

LaHuffman-Jackson, R. (2009). An analysis of the impact of working conditions on teacher turnover in low performing school in North Caroline. (Unpublished doctoral dissertation). Fayetteville State University. Fayetteville, North Caroline.

Memur Sen (2014). Mart ayı açlık ve yoksulluk araştırması http://www.memursen.org.tr/haber/memur-sen-mart-ayi-aclik-ve-yoksullukarastirmasi adresinden alınmıştır.

Merkezi Yönetim Bütçe Kanunu (2011). 2012 yılı merkezi yönetim bütçe kanunu. Kanun No. 6260. Resmî Gazete, 28157 (Mükerrer): 2012 Y1lı Merkezi Yönetim Bütçe Kanunu İcmali (I) Sayılı Cetvel - Genel Bütçeli İdareler (Ekonomik Siniflandirma).

Merkezi Yönetim Bütçe Kanunu Tasarısı (2015). 2015 yılı merkezi yönetim bütçe kanunu tasarısı ve bağlı cetveller. http://pbk.tbmm.gov.tr/dokumanlar/2015_merkezi_yonetim_butce_tasarisi.pdf adresinden alınmıştır.

Mason J. (2002). Qualitative researching (2nd. Ed.). London: Sage Publications Ltd.

MEB (1973). Milli Eğitim Temel Kanunu. Kanun Numarası: 1739. Resmi Gazete, Say1: 14574.

MEB (2014). MEB İstatistikleri, Örgün Eğitim. 2013-2014. İndirilme tarihi: 12.12.2014http://sgb.meb.gov.tr/www/milli-egitim-istatistikleri-orgun-egitim-20132014/icerik/95 adresinden alınmıştır.

OECD, (2009) Teaching and learning international survey: Creating effective teaching and learning environments first results from TALIS. Retrieved from http://www.oecd.org/document/50/0,3746,en_2649_3926.

3231_47786442_1_1_1_1,00.html.

OECD, (2012). Statistics from A to Z. teachers' salaries education: Key tables from OECD. Retrieved from http://www.oecd-ilibrary.org/education/teacherssalaries_teachsal-table-en.

ÖSYM (2014) Kamu Personeli Seçme Sınavı Öğretmenlik Alan Bilgisi Testi (ÖABT) Sonuçları.http://dokuman.osym.gov.tr/pdfdokuman/2014/KPSS/OABTSORUYANIT/KPSS-2014-OABTsayisal25072014.pdf adresinden alınmıştır.

Özden, Y. (1999). Eğitimde dönüşüm eğitimde yeni değerler. Ankara: Pegem A Yayınları.

Özder, H., Konedralı, G., \& Zeki, C. P. (2010). Öğretmen adaylarının öğretmenlik mesleğine yönelik tutumlarının çeşitli değişkenler açısından incelenmesi. Kuram ve Uygulamada Eğitim Yönetimi. 16 (2), 253-275. 
Patton, M. Q. (1990). Qualitative evaluation and research (2nd. Ed.). California, USA: Sage Pub. Inc.

Rubin, H. \& Rubin, I. (1995). Qualitative interviewing: The art of hearing data. Thousand Oaks, CA: Sage.

Sabanc1, A. (2008). Eğitbilimine giriş. E.Toprakçı (Ed.). içinde, Eğitimin temel kavramları, (ss. 13-40). 1. Bask1. Ankara: Ütopya Yayınları.

Sabanci, A. (2009). The effect of primary school teachers' burnout on organizational Health. Procedia Social and Behavioral Sciences, 1, 195-205.

Sabanci, A. (2011). The effect of teachers' stress on educational organizations' health. International Journal of Business and Social Science, 2(11), 91-100.

Şişman, M. (1999). Öğretmenliğe giriş. Ankara: Pegem A Yayınları.

Türkiye İşçi Sendikaları Konfederasyonu (2014). Kasım 2014 Açlık ve Yoksulluk Sınırı Türk İş Haber Bülteni. http://www.turkis.org.tr/dosya/nkhl6TSnMiZH.pdf adresinden alınmıştır.

Ubuz, B. \& Sarı, S. (2008). Sınıf öğretmeni adaylarının öğretmenlik mesleğini seçme nedenleri. Pamukkale Üniversitesi Eğitim Fakültesi Dergisi, 24, 113-119.

Yazıcı, H. (2009). Öğretmenlik mesleği, motivasyon kaynakları ve temel tutumlar: Kuramsal bir bakış. Kastamonu Ĕ̆itim Dergisi, 17(1), 33-46.

Yıldırım, A. \& Şimşek, H. (2006). Sosyal bilimlerde araştırma yöntemleri. 6. Baskı. Ankara: Seçkin Yayıncılık. 